\title{
Academic mobility of doctoral students in Brazil: An analysis based on Lattes Platform
}

Higor Mascarenhas1, Thiago Magela Rodrigues Dias2, Patrícia Dias3

How to cite (APA): Mascharena, H.; Dias, T.M. R. \& Días, P. (2021). Academic mobility of doctoral students in Brazil: An analysis based on Lattes Platform. Iberoamerican Journal of Science Measurement and Communication;

1(3), 1-15. https://doi.org/

$10.47909 /$ ijsmc.53

Received: 20-05-2021

Accepted: 09-11-2021

Handling Editor: Carlos Luis González-Valiente

Copyright: (c) 2021 Mascharena et al. This is an open access article distributed under the terms of the CC BY-NC 4.0 license which permits copying and redistributing the material in any medium or format, adapting, transforming and building upon the material as long as the license terms are followed.

\section{ABSTRACT}

Objective. In this article, the academic mobility of Brazilian doctoral students moving from their home cities to other Brazilian cities including other countries is examined.

Design/Methodology/Approach. The LattesDataXplorer tool was used to extract curriculum data from the Lattes Platform. 308,317 resumes were collected in May 2019, since then the data have been filtered, obtaining relevant data for the research. After extracting the data, they were enriched with the integration of other data sources, thus enabling the characterization of bibliometric networks for the analyses.

Results/Discussion. It was possible to measure distances traveled by Brazilian doctors throughout their academic training, as well as to point out the cities, states, and countries whose doctors most meet in the academic journey and the relationships between these locations. Thus, making it possible to obtain a portrait of how the Brazilian scientific exodus occurs. In general, more than $90 \%$ of curricula have information on the academic background at each level of education. The average distance of $291 \mathrm{~km}$ between birth and place of formation at the graduation level is strongly influenced by outliers. Individuals choose to travel shorter distances throughout the academic training process, being the geographic location a strong influence on the migratory process for training.

Conclusions. The United States represents the country where individuals choose to move

1 Centro Federal de Educação Tecnológica de Minas Gerais (CEFET-MG), Belo Horizonte, Minas Gerais, Brazil. Email: higoralexandre1996@gmail.com, ORCID: 0000-0002-6424-996X

2 Centro Federal de Educação Tecnológica de Minas Gerais (CEFET-MG), Belo Horizonte, Minas Gerais, Brazil. Email: thiagomagela@gmail.com, ORCID: 0000-0001-5057-9936

3 Instituto de Investigaciones Económicas y Sociales del Sur, Brazil. Email: patriciamdias@gmail.com, ORCID: 0000-0002-8448-6874 
the most. Regarding international migration, there is more preference for European countries than South American ones. When it comes to intra-regional migration, students prefer those states where the most relevant universities are located.

Originality/Value. The article presents the results of original research focusing on the Brazilian scientific community. Distances performed by doctoral students throughout their academic trajectory are measured, as well as the main locations where they tend to move.

Keywords: Academic mobility, Lattes Platform, Doctoral students, Brazil, Scientific exodus

\section{INTRODUCTION}

The emigration of Brazilian people to other countries, and even to other Brazilian states, has increased significantly. Some studies show that certain cities have rates of $10-30 \%$ of migrants who do not live in their home state (Abel \& Sander, 2014). In the case of students, one of the main causes of academic mobility within Brazil is conditioned by the search for the higher education of quality, new professional opportunities, and more experiences in their areas (Lombas, 2017). While many students feel the motivation to leave to other countries seeking cultural exchange and better investment in research grants. The student's mobility abroad is not only of interest of the student itself but of the origin institutions, as students tend to return with enriched academic productivity, extensive contact network, greater experience, and more knowledge to share in the home institution.

According to Demartini (2017), performing scientific research is becoming more difficult in Brazil because of the reduction of funds for the educational sector. The lack of government support is considered as one of the main reasons why Brazilian researchers go to study abroad. Consequently, most of the Brazilian scientists do not work in their area of training when they return, so they do not progress in their careers (Demartini, 2017).

'Science without Borders' (Ciência sem Fronteiras, in Portuguese) is a program that has aided a lot of students by providing scholarships. In 2015, the Brazilian government planned to reach 101,000 scholarships for researchers, graduates, doctoral and post-doctoral students, encouraging them to teach in institutions of recognized prestige (Aveiro, 2014). Today, with only 5,000 scholarships available, this program has lost a lot of its availability to send local students to other countries because of the fund reductions factor. From this scenario, this article will examine the academic mobility of doctoral students moving from their home cities to other Brazilian cities including other countries. These analyzes make it possible to understand how Brazilian students have moved in their training processes and thus verify the influence of the absence of universities in certain locations, providing subsidies for policies to implement new educational institutions in these locations

\section{Related Works}

On an international scale, Abel and Sander (2014) carried out an analysis of the migratory flow of people born in 196 countries from around the world, during the mid-1990s until 2010. Intending to understand immigration patterns and trends across the sampled countries and continents, the authors identified the mobility flows of individuals according to the development level of the countries.

In the Gureyev et al. (2020) study, scientific mobility in the last 30 years is analyzed using bibliometric approaches. The main evolutionary stages of scientific mobility were traced in the context of the concepts of brain drain and circulation, including the relationships, 
advantages, and disadvantages of scientific mobility concerning scientific consanguinity. Furthermore, the authors describe the main methodological approaches and aspects formed today in the study of the mobility of scientists. It is also discussed the positive and negative consequences of mobility for researchers, organizations, countries, and individual disciplines, and the motivations and driving forces of scientists leaving the country and returning are summarized.

Kosztyán et al. (2021) proposed a method based on a multilayer network to measure the insertion of universities in collaboration and mobility networks. Several advantages of the proposed method are pointed out, such as its relevance to the main missions of the institutions, the introduction of a new complementary dimension to the existing classifications; size invariant; and transparency. The proposed multilayer network approach allows for the integration of other networks, which creates opportunities for a more comprehensive assessment of the performance of universities in fulfilling their core missions. It is also worth mentioning other works that have explored academic mobility like Dubois et al. (2014), Albarrán et al. (2017), and Sachini et al. (2020), for example.

While concerning the Brazilian context, several studies reflect the interest in examining the academic mobility phenomenon. Using the Lattes Platform as the data source, Chavez and Duarte (2015) examined the trajectory of postgraduate researchers from their birth till their last formation degree. Concerning the doctoral students, they evidenced that $95 \%$ were from the South, Southeast, and Northeast states. Meanwhile, $40 \%$ of the first doctoral training courses were carried out in the cities of origin and $87 \%$ of those students moved to other cities not exceeding or within the limit of $1,000 \mathrm{~km}$. São Paulo is highlighted as the city with the highest number of Ph.D. students. Likewise, Pierro (2016) analyzed the mobility of Brazilian researchers and students throughout their academic training. The author evidenced that $20 \%$ of the researchers work in institutions located more than $500 \mathrm{~km}$ far from where they studied, while the majority work at about $100 \mathrm{~km}$ far. This kind of mobility aided researchers to be involved in several research lines, making them gain more recognition. This study also indicates that states in the southeastern region, mainly São Paulo, are those where most of the researchers are coming from, while a temporary migratory pattern was seen in other states.

Andrade (2019) studied the circulation of people throughout their academic journey, as well as their workday. In the study, the author mentioned those researchers choosing to engage in mobility or obtain more experience in their area and expand their networks at other universities. Referring to the Brazilian context, the author mentioned that there is no way to motivate native students to move abroad, which affects the increase of networking between Brazilian and foreign researchers. However, Brazil invests to bring foreign researchers to study in the country, which becomes difficult given the scholarship reduction. Andrade (2019) points out that countries like China invest to increase the academic connections with other countries, being the United States the country where most of the Chinese people tend to move. Meanwhile, Silva and Queiroz (2020) analyzed the evolution of intra-state migration in the Rio Grande do Norte region during the periods 1995-2000 and 2005-2010, emphasizing the mobility between the Metropolitan Region of Natal (RMN) and the interior of the state. The authors evidenced a high volume of mobility "from" and "to" the interior of Rio Grande do Sul, something conditioned by the concentration of activities related to service, commerce, tourism, and education sectors. 


\section{METHODOLOGY}

For this study, we analyzed the curriculums of those Brazilian individuals who completed their doctoral degrees in every discipline, regardless of the year of study completion. We employed the Lattes Platform as the data source. The data was extracted via the LattesDataXplorer (Dias, 2016) since only one curriculum can be accessed per time, being a limitation at the time to process many curricula. A total of 308,317 curriculums were extracted in May 2019. At that time, this amount represented around $4 \%$ of the registered curriculums. After the data extraction process, we performed the data selection and processing as displayed in Figure 1.

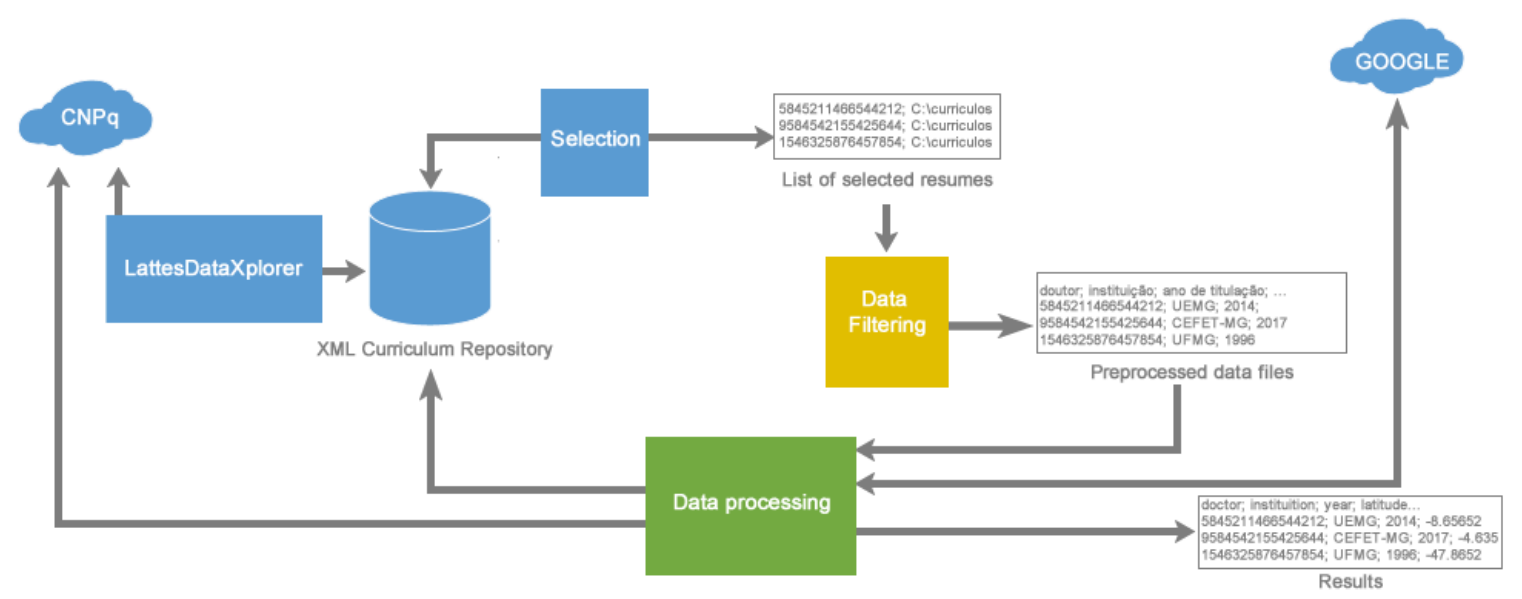

Figure 1. Methodological procedures regarding the data selection and processing.

In the "Selection" step, the XPath query language (XML Path Language) was used for research, and the subsequent generation of a subgroup was generated to be further analyzed. The XPath language allowed the construction of expressions that went through the $\mathrm{XML}$ document in a similar way to the use of regular expressions. Therefore, it was possible to group sets of curricula under desired parameters, such as 'academic training' or 'areas of expertise'.

Thus, it was possible to obtain a list storing the identifiers of each curriculum and the path where it was stored locally, being possible to analyze only the selected curricula. Given the above, only curricula were collected from individuals with completed doctoral degrees, as this is the group with the highest academic level. Besides, these curricula are frequently updated and most of the parameters required for current jobs are registered in their curricula.

After selecting the set to be analyzed, the "Data filtering" module, which was responsible for analyzing the resumes in XML files, features an extract of formatted data (Preprocessed data files). The curriculum information registered in the file had a curriculum identifier; individual's state and city of birth; institution code, name, and zip code of the current employer, such as the identification code and institution name of each level of education completed. Afterward, the module "Data processing" (see Figure 2) was executed, in which four steps were performed: (1) institution's CEP obtention; (2) geographic location search; (3) data cleaning and grouping, and (4) data normalization.

Through step 1 (institution's CEP obtention), we obtained institutions' data including data, characteristics, and zip code. Concerning step 2, 'geographic location search', we obtained institutions' geographic location (latitude and longitude) employing the Google geolocation API. During step 3 (data cleaning and grouping), irrelevant terms were excluded like stop 
words in city names, and words with accents were normalized. Finally, in the 'data normalization' step, information redundancy was reduced by discarding attributes with the absence of data, such as CEP with no digits. Subsequently, a 'Results File' was generated, which contained a summary of all data obtained from the curricula of all the Brazilian Ph.D. holders.

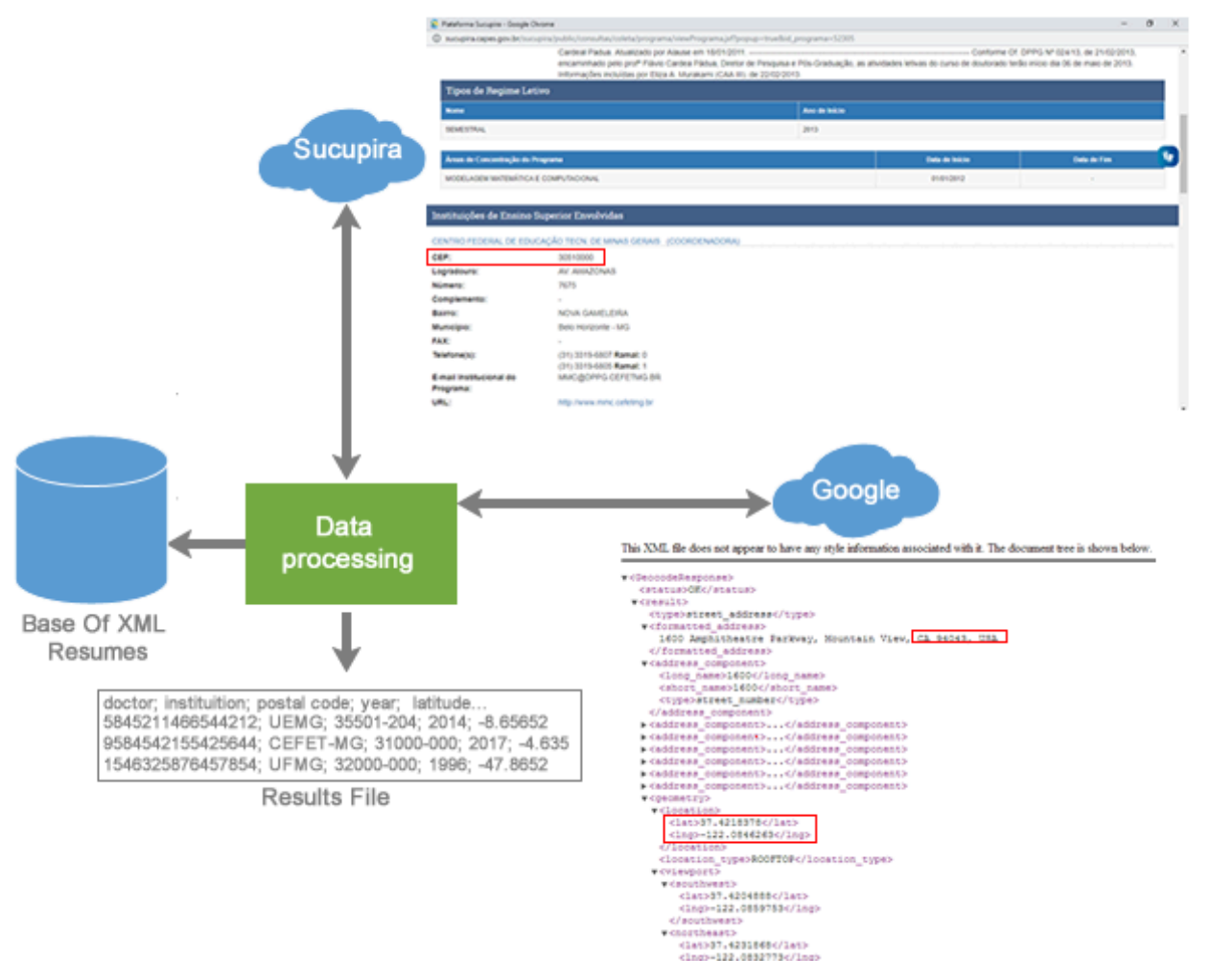

Figure 2. Data processing procedure.

After all the steps described above, several metrics were applied such as analysis of link networks, means for statistical calculations of distances covered by Brazilian doctors to understand how the mobility of Brazilian Ph.D. holders occurred throughout their academic training process.

For specific analyzes on the process of migration to training, networks of locations were characterized considering each change in the links considered as edges of the network. For the analysis based on network metrics, the Gephi software version 9.2 was used. Thus, the variables used were names of Brazilian doctors, city of birth, city of operation, as well as city corresponding to the location of education levels. It was decided to use dictated networks, containing weights on their edges, using the distributions of Fruchterman Reingold, and Force Atlas, so it was possible to obtain the characterized networks.

\section{RESULTS AND DISCUSSIONS}

Figure 3 shows the number of curricula that have attributes registered in the Lattes Platform, such as the city of birth, the institution in which they are working, and formation institutions. Most individuals have their birth city registered totaling 293,340 (95\%) records, as this is a mandatory field when registering on the Platform. Those individuals without a birth city registration are considered as with 'older curricula' since the city registration was not 
mandatory. Of the other institutions shown in Figure 1, the one prevailing in terms of quantitative data is the Institution of completion of the Ph.D. degree, totaling 297,815 (96\%) registrations. This is the group selected for this study. The postdoctoral institution is the one with the lowest number of registrations, totaling $70,405(22 \%)$. This might occur because we selected individuals who completed their doctoral degrees since an individual holding a Ph.D. does not always have a postdoctoral degree.

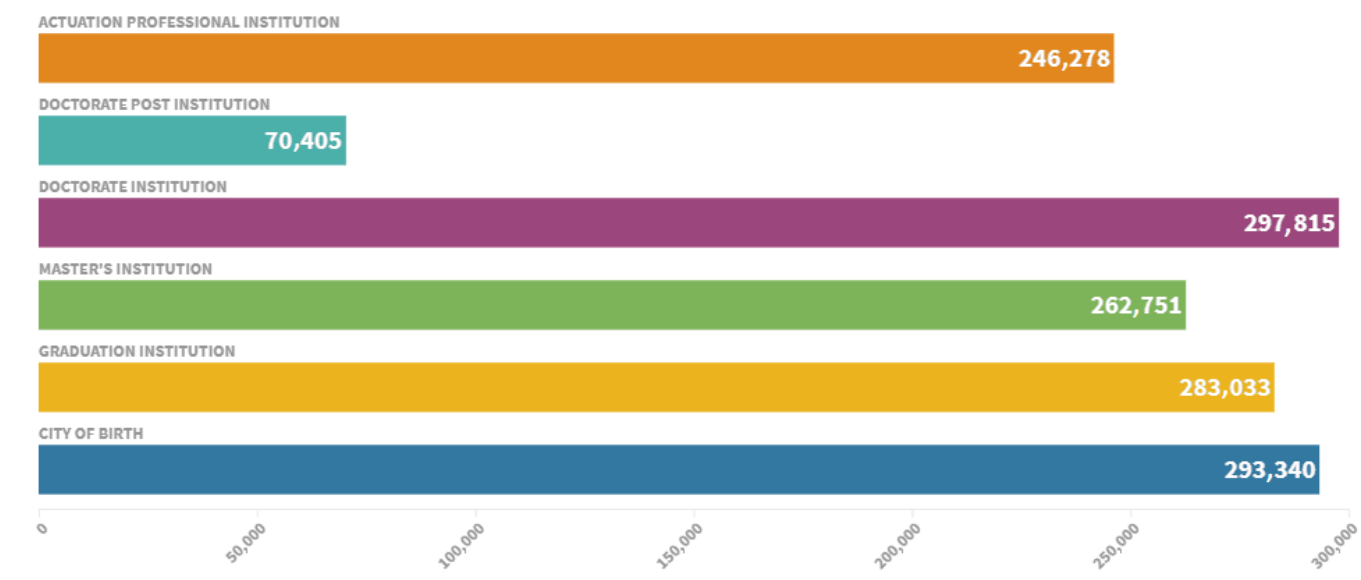

Figure 3. Quantitative data of the curricula analyzed in the study.

Table 1 shows the average distances in kilometers between one level of training to another. We notice that the shortest distance is given for graduate studies. It is a fact that most of the Brazilian cities offer undergraduate courses and if not, these courses can also be found in nearby cities. However, the greatest distances are detected for the doctoral level.

\begin{tabular}{llll}
\hline Distance $(\mathrm{Km})$ & Graduation & Master's degree & Ph.D. degree \\
Birth & 291.58 & 548.59 & $1,000.75$ \\
Graduation & - & 432.38 & 901.26 \\
Master's degree & - & - & 619.00
\end{tabular}

Table 1. Average distance in kilometers according to education degrees.

\section{Social network analysis of Brazilian mobility}

In Figure 4, a representation of the linkage between Brazilian states and several countries is made. They all are directed networks where nodes represent locations in which students were trained, and edges represent the interaction between places. The diameter of each knot characterizes the number of degrees it has. Networks displayed in Figure 4 do not have isolated components, since all links have a node characterizing the entry (being represented as the emigration location) and another node as the destination (representing the immigration location). 

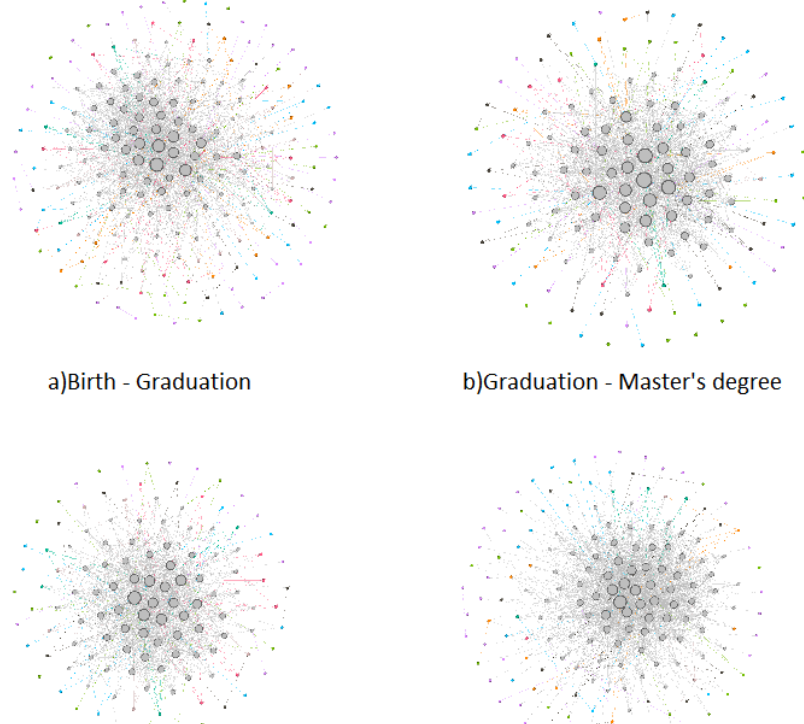

b)Graduation - Master's degree

c)Master's degree - Doctorate

d)Doctorate - Professional performance

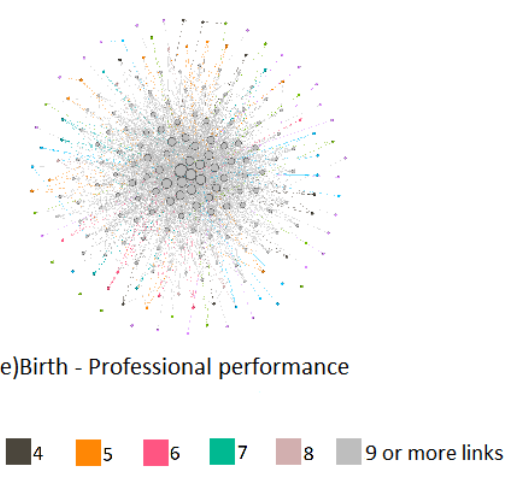

Figure 4. International link networks.

We observe that some networks have a lower number of nodes than others, as in the case of Figures $4 \mathrm{~b}$ and $4 \mathrm{c}$. Both networks represent those individuals who prefer to remain in the same place when it comes to undergraduate, master, and doctoral degrees. In Figures $4 a$ and $4 \mathrm{e}$, a greater number of links are generated.

A network was created with all the links obtained from the birth data, using all levels of education, and professional performance (see Figure 5), just not considering the birthplace for professional performance. In this network, all nodes belong to a giant component, having no isolated component, and the greatest number of nodes with degrees whose degree value is greater than 9 stands out. It was observed that all Brazilian states are present in this network, with a degree higher than 9 . Nodes with a degree value greater than 60 have links with several nodes greater than themselves. 


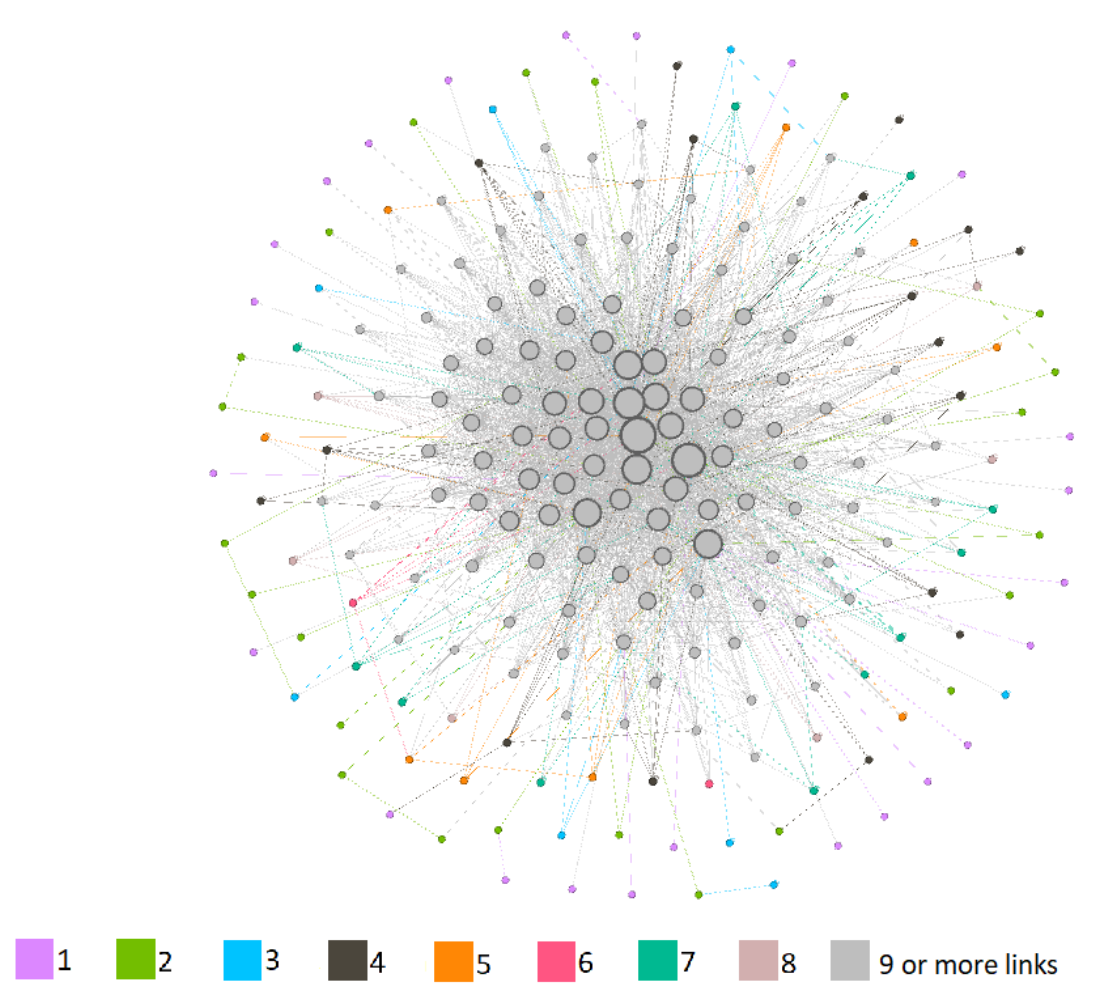

Figure 5. Network of links of all education degrees at the international scale.

Table 2 summarizes the statistical information of the networks. When comparing the number of nodes and edge rate in the Giant Component with the global network, it is noticed that the network standing out the most is the one containing all the links (see Figure 5), since it has the largest connected Giant Component (100\% of the edges and nodes). This is different from the other networks, in which the values of the node rates are also high, but with a lower percentage than the network of all links. As far as density is concerned, the network with all links has the third-lowest value, different from the master and Ph.D. networks containing the highest densities. This might occur because of the collaboration networks among individuals who are transitioning from one educational level to another.

\begin{tabular}{|c|c|c|c|c|c|c|}
\hline Metrics & Birth-Grad & Grad-Mest & Mest-Doct & Doct-Actuation & All & Birth-Actuation \\
\hline $\begin{array}{l}\text { Number of } \\
\text { nodes }\end{array}$ & 201 & 144 & 124 & 174 & 217 & 210 \\
\hline $\begin{array}{l}\text { Number of } \\
\text { Edges }\end{array}$ & 2,246 & 1,814 & 1,84 & 2,297 & 4,039 & 3,389 \\
\hline $\begin{array}{l}\text { Average } \\
\text { degree of } \\
\text { nodes }\end{array}$ & 11174 & 12597 & 14839 & 13201 & 18613 & 16138 \\
\hline $\begin{array}{l}\text { Nodes of } \\
\text { G.C. }\end{array}$ & 189 & 135 & 119 & 171 & 217 & 206 \\
\hline
\end{tabular}




\begin{tabular}{|c|c|c|c|c|c|c|}
\hline $\begin{array}{l}\% \text { of nodes } \\
\text { in the } \\
\text { Gigant } \\
\text { Component }\end{array}$ & 94.03 & 93.75 & 95.97 & 98.28 & 100 & 98.1 \\
\hline $\begin{array}{l}\text { Edges of } \\
\text { Gigant } \\
\text { Component }\end{array}$ & 2,237 & 1,805 & 1,835 & 2,295 & 4,039 & 3,385 \\
\hline $\begin{array}{l}\% \text { of edges } \\
\text { in the } \\
\text { Gigant } \\
\text { Component }\end{array}$ & 99.99 & 100 & 99.72 & 99.91 & 100 & 99.88 \\
\hline $\begin{array}{l}\text { Network } \\
\text { Density }\end{array}$ & 56 & 88 & 121 & 76 & 86 & 77 \\
\hline $\begin{array}{l}\text { Network } \\
\text { Diameter }\end{array}$ & 5 & 5 & 5 & 5 & 6 & 5 \\
\hline $\begin{array}{l}\text { Average } \\
\text { path length }\end{array}$ & 2321 & 2106 & 2009 & 2182 & 2261 & 9 \\
\hline
\end{tabular}

Table 2. Statistical data derived from the international network maps.

The largest diameter is represented by the network of all links (value equal 6), where there are 5 nodes between the two most distant nodes. The other networks have the same diameter value totaling 5 , in which the two most distant nodes need to travel 4 nodes to meet.

The network referred to as 'birth-graduation' (see Figure 4a) has the lowest average degree of nodes, which is caused because some nodes have a low degree value since they do not have large amounts of bonds but decreasing degree value. Unlike the network with all links of the highest average degree value, where nodes with the highest grades increase in terms of average. Concerning the average minimum path, we observe that networks have very close values (approximately 2). On average, it only takes two edges to reach a given node from any other node of the network.

To expand our analysis and obtain a better view of the states and countries that have the highest in-degrees of entry (number of edges that fall on the node), we generated the network presented in Figure 6 . We highlight the high density of this network since all nodes are connected. All states from the South, Midwest, and Southeast regions of Brazil are present, with a hypothesis for this the number of universities inserted to these regions. The North and Northeast regions display a lower number of states. 


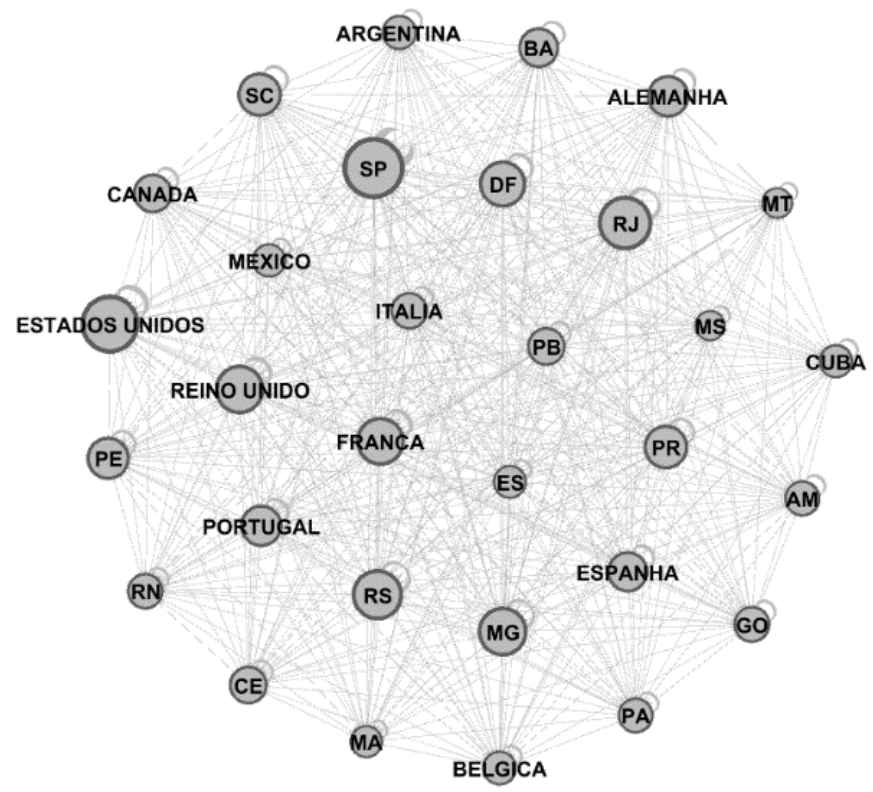

Figure 6. Link networks with higher in-degrees of entry.

When observing the countries present in the network, Argentina appears as the only South American country. While Cuba, Mexico, Canada, and the United States stand out as the largest country nodes, containing the greatest number of ties. The United States stands out with the highest degree value, being inferior only to the São Paulo state. Some possible reasons why the United States has the highest degree among nodes are its good economy, language, and scholarship offers. When it comes to the European countries, the United Kingdom, France, Portugal, Germany, Spain, Belgium, and Italy highlight the highest in-degrees of entry.

\section{Academic mobility at a national level}

Table 3 shows the main links between Brazilian cities, by which we notice that the geographic region is a key factor during the mobility process. In Table 3 , the data presented on the left have locations as the origin and destination of a link traveled by doctoral students. While on the left side of the table, the intra-municipal/intra-regional column represents those individuals who continued in their homes.

\begin{tabular}{llclc}
\hline Origin & Destination & Quantity & Intra-municipal & Quantity \\
São Paulo-SP & Campinas-SP & 6,151 & São Paulo-SP & 103,979 \\
Rio de Janeiro-RJ & Niterói-RJ & 4,888 & $\begin{array}{l}\text { Rio de } \\
\text { Janeiro-RJ }\end{array}$ & 62,896 \\
Niterói-RJ & Rio de Janeiro-RJ & 4,418 & Porto Alegre-RS & 29,093 \\
Campinas-SP & São Paulo-SP & 4,327 & $\begin{array}{l}\text { Belo } \\
\text { Horizonte-MG }\end{array}$ & 23,935
\end{tabular}




\begin{tabular}{|c|c|c|c|c|}
\hline São Paulo-SP & São Carlos-SP & 3,084 & Campinas-SP & 21,031 \\
\hline Rio de Janeiro-RJ & São Paulo-SP & 2,699 & Recife-PE & 19,042 \\
\hline São Paulo-SP & Rio de Janeiro-RJ & 2,408 & Fortaleza-CE & 14,700 \\
\hline São Carlos-SP & São Paulo-SP & 2,277 & Curitiba-PR & 13,672 \\
\hline São Paulo-SP & Ribeirão Preto-SP & 1,969 & Florianópolis-SC & 13,058 \\
\hline Santa Maria-RS & Porto Alegre-RS & 1,780 & Salvador-BA & 10,757 \\
\hline Curitiba-PR & São Paulo-SP & 1,619 & Brasília-DF & 10,751 \\
\hline São Paulo-SP & Curitiba-PR & 1,524 & Belém-PA & 8,293 \\
\hline São Paulo-SP & Brasília-DF & 1,507 & Santa Maria-RS & 7,205 \\
\hline Rio de Janeiro-RJ & Seropédica-RJ & 1,495 & Viçosa-MG & 7,029 \\
\hline Belo Horizonte-MG & São Paulo-SP & 1,461 & Natal-RN & 7,028 \\
\hline Ribeirão Preto-SP & São Paulo-SP & 1,458 & João Pessoa-PB & 6,737 \\
\hline Londrina-PR & São Paulo-SP & 1,413 & Goiânia-GO & 5,873 \\
\hline $\begin{array}{l}\text { Campina } \\
\text { Grande-PB }\end{array}$ & João Pessoa-PB & 1,347 & São Carlos-SP & 5,308 \\
\hline Porto Alegre-RS & São Paulo-SP & 1,300 & Niterói-RJ & 5,202 \\
\hline São Paulo-SP & Belo Horizonte-MG & 1,245 & Pelotas-RS & 4,779 \\
\hline São Paulo-SP & Londrina-PR & 1,221 & Maringá-PR & 4,665 \\
\hline Recife-PE & São Paulo-SP & 1,189 & Lavras-MG & 4,257 \\
\hline São Paulo-SP & $\begin{array}{l}\text { São José dos } \\
\text { Campos-SP }\end{array}$ & 1,153 & Uberlândia-MG & 4,189 \\
\hline Pelotas-RS & Porto Alegre-RS & 1,128 & Londrina-PR & 3,477 \\
\hline São Paulo-SP & Florianópolis-SC & 1,125 & Vitória-ES & 3,229 \\
\hline
\end{tabular}

Table 3. Results of the national mobility linkage.

When it comes to origin and destination between cities, we notice a high mobility flow between the cities of São Paulo and Campinas. Campinas stands out as a destination city given the presence of the University of Campinas (UNICAMP), which contains around seventy undergraduate courses, and graduate courses in several fields like biology and health, arts, 
humanities, exact sciences, technology, and earth. This university highlights the Institute of Biology since it has reached national and international recognition in the biological sciences. São Paulo, on the other hand, has several higher education centers, being the University of São Paulo (USP) the largest and most important university in the country. The USP is offering several courses in many knowledge areas placed in more than 30 locations across São Paulo.

It is worth mentioning the high number of individuals moving from Rio de Janeiro to Niterói and vice versa. Both cities have a strong academic connection. In Rio de Janeiro is located Federal University of Rio de Janeiro (UFRJ), which offers 172 undergraduate courses and about 232 master and doctorate courses. According to the Folha 2019 University Ranking (Anon [s.d.]), the UFRJ is the most innovative university in the country. While in Niterói city, it is located the Federal Fluminense University (UFF), which the faculties of Law and Nursing highlights.

We consider the relevance of the mobility from São Paulo to São Carlos. São Carlos is a potential destination for those focused on the exact sciences, because of the presence of the USP campuses. In the Ribeirão Preto, there is visible a high number of mobility given some campuses of the USP, highlighting in this case centers focused on health sciences. Another interesting path is given from Rio de Janeiro to São Paulo and the way around. In these cities, the UFRJ and USP are located respectively, where a possible network between advisors is established.

Another relevant mobility takes place to the Belo Horizonte city, where the Federal University of Minas Gerais (FUMG) resides. This university offers many undergraduate and graduate courses, and it is a national reference in terms of higher education levels. The cities of Lavras and Viçosa in Minas Gerais highlight in this case given the presence of undergraduate and graduate courses in many fields as well.

\section{Mobility at an international level}

Our next analysis is oriented to international mobility, in this regard, Table 4 shows the statistical results. As it can be seen, the United States is the country where most of the individuals tend to migrate, specifically those coming from three states from the southeast region of Brazil. The United States also has the largest number of ties as intra-regional, conditioned by those individuals who remain in the country throughout their academic training. Let us bear in mind that the United States has the four best universities in the world according to the QS World University Rankings 2021 (Anon [s.d.]).

\begin{tabular}{lllll}
\hline Origin & Destination & Quantity & Intra-regional & Quantity \\
São Paulo & United States & 2.355 & United States & 4.421 \\
United States & São Paulo & 2.168 & Portugal & 3.504 \\
Rio de Janeiro & United States & 1.284 & France & 2.929 \\
United States & Rio de Janeiro & 1.199 & Spain & 2.638 \\
Minas Gerais & United States & 829 & Argentina & 1.844
\end{tabular}




\begin{tabular}{|c|c|c|c|c|}
\hline São Paulo & United Kingdom & 731 & Colombia & 1.776 \\
\hline United Kingdom & São Paulo & 723 & Peru & 1.455 \\
\hline France & São Paulo & 711 & Cuba & 1.340 \\
\hline United States & Minas Gerais & 693 & Italy & 1.213 \\
\hline São Paulo & France & 652 & Germany & 1.205 \\
\hline Rio Grande do Sul & United States & 635 & India & 677 \\
\hline Rio de Janeiro & United Kingdom & 603 & Canada & 630 \\
\hline France & Rio de Janeiro & 580 & United Kingdom & 608 \\
\hline United Kingdom & Rio de Janeiro & 568 & Mexico & 598 \\
\hline Rio de Janeiro & France & 547 & Chile & 559 \\
\hline Peru & São Paulo & 530 & Russia & 406 \\
\hline United States & Rio Grande do Sul & 472 & Venezuela & 344 \\
\hline Colombia & São Paulo & 465 & Belgium & 337 \\
\hline United States & Distrito Federal & 452 & Uruguay & 334 \\
\hline Portugal & Rio de Janeiro & 435 & Japan & 234 \\
\hline Rio de Janeiro & Portugal & 435 & Paraguay & 188 \\
\hline Portugal & São Paulo & 404 & Australia & 145 \\
\hline Rio Grande do Sul & France & 373 & Bolivia & 129 \\
\hline Argentina & São Paulo & 372 & Switzerland & 128 \\
\hline Alemanha & São Paulo & 359 & Netherlands & 115 \\
\hline
\end{tabular}

Table 4. Results of the international mobility linkage.

We also observe that Portugal is the second country of destination, which is understandable given it shares the same language as Brazil and is given easy access to the country. European countries such as France and Spain stand out among the largest links at the international level. On the other hand, the United Kingdom stands out as a destination for individuals from São Paulo and Rio de Janeiro. This country has four of the ten best universities worldwide according to the QS World University Rankings 2021. Meanwhile, the most relevant destinations in South America are Argentina, Colombia, Peru, and, at a lower level, countries like Venezuela, Uruguay, Paraguay, and Bolivia respectively. 


\section{CONCLUDING REMARKS}

Across the findings of this study, we evidenced that the southeast region in Brazil and the Rio Grande do Sul concentrate most of the Brazilian Ph.D. holders. Let us bear in mind that in these locations reside the main public universities in the country. The United States stands out as the country where most of the Brazilian fellows tend to move. Besides, there is higher mobility in European countries than the South American ones.

We consider that academic mobility is an important mechanism to measure the impact of the courses offered in the academic training process and on the job offer for individuals with a doctoral degree. Specifically, in this study, it was noticed that the states holding the main educational institutions in the country are exactly those having the highest in-degrees in the characterized networks. On the other hand, it is also verified that those regions with the lowest values of in-degrees are those that are farthest from the main states of the country.

Further explorations of this topic should consider a longitudinal perspective. Analyzing academic mobility over time will aid evidence of how mobility between cities, institutions, and countries has evolved.

\section{Conflicts of interest statement}

The authors declare that there is no conflict of interest.

\section{Statement of data consent}

The data generated during the development of this study has been included in the manuscript.

\section{REFERENCES}

Albarrán, P., Carrasco, R. \& Ruiz-Castillo, J. (2017). Geographic mobility and research productivity in a selection of top world economics departments. Scientometrics 111, 241-265. https://doi.org/10.1007/s11192-017-2245-x

Andrade, R. O. (2019). O impacto da circulação de cérebros. Pesquisa Fapesp 8.

Anon. [s.d.]. QS World University Rankings 2021. Top Universities. Retrieved from https://www.topuniversities.com/university-rankings/world-university-rankings/2021

Anon. [s.d.]. Ranking de universidades - RUF 2019 | Folha. RUF: Ranking Universitário Folha. Retrieved from //ruf.folha.uol.com.br/2019/ranking-de-universidades/principal/

Aveiro, T. M. M. (2014). O programa Ciência sem Fronteiras como ferramenta de acesso à mobilidade internacional. \# Tear: Revista de Educação, Ciência e Tecnologia, 3(2). https://doi.org/10.35819/tear.v3.n2.a1867

Chaves, L., \& Duarte, A. (2015). Analisando a mobilidade de pesquisadores através de registros curriculares na Plataforma Lattes. In Anais do IV Brazilian Workshop on Social Network Analysis and Mining. Porto Alegre: SBC. https://doi.org/10.5753/brasnam.2015.6774

Demartini, M. (2017, Februry). Falta de oportunidades mantém cientistas brasileiros no exterior. Exame. Retrieved from https://exame.com/ciencia/ falta-de-oportunidades-mantem-cientistas-brasileiros-no-exterior/ 
Dias, T. M. R. (2016). Um estudo da produção científica brasileira a partir de dados da Plataforma Lattes. 2016. Doutorado em Modelagem Matemática e Computacional. Centro Federal de Educação Tecnológica de Minas Gerais, Belo Horizonte, CEFET-MG, Belo Horizonte.

Dubois, P., Rochet, J.C. \& Schlenker, J.M. (2020). Productivity and mobility in academic research: evidence from mathematicians. Scientometrics, 98, 1669-1701 (2014). https://doi.org/10.1007/s11192-013-1112-7

Gureyev, V. N., Mazov, N. A., Kosyakov, D. V., \& Guskov, A. E. (2020). Review and analysis of publications on scientific mobility: assessment of influence, motivation, and trends. Scientometrics, 124, 1599-1630. https://doi.org/10.1007/s11192-020-03515-4

Kosztyán, Z.T., Fehérvölgyi, B., Csizmadia, T. et al. Investigating collaborative and mobility networks: reflections on the core missions of universities. Scientometrics 126, 3551-3564 (2021). https://doi.org/10.1007/s11192-021-03865-7

Lombas, M. L. D. S. (2017). A mobilidade internacional acadêmica: características dos percursos de pesquisadores brasileiros. Sociologias, 19, 308-333. https://doi.org/10.1590/ $15174522-019004413$.

Pierro, B. (2016). Circulação limitada. Pesquisa Fapesp (239), 4.

de Souza Silva, P., \& de Queiroz, S. N. (2020). Migração intraestadual no Rio Grande do Norte: estudo a partir dos fluxos RMN-interior e interior-RMN. Ideias, 11, e020008-e020008. https://doi.org/10.20396/ideias.v11i0.8658503

Sachini, E., Karampekios, N., Brutti, P., \& Sioumalas-Christodoulou, K. (2020). Should I stay or should I go? Using bibliometrics to identify the international mobility of highly educated Greek manpower. Scientometrics, 125(1), 641-663. https://doi.org/10.1007/ s11192-020-03618-y 